\title{
The influence of persistent pathogens on circulating levels of inflammatory markers: a cross-sectional analysis from the Multi-Ethnic Study of Atherosclerosis
}

\author{
Aydin Nazmi ${ }^{1}$, Ana V Diez-Roux ${ }^{2}$, Nancy S Jenny ${ }^{3}$, Michael Y Tsai ${ }^{4}$, Moyses Szklo ${ }^{5}$, Allison E Aiello ${ }^{2 *}$
}

\begin{abstract}
Background: Systemic inflammation is linked to cardiovascular risk, but the influence of persistent pathogens, which are conventionally dichotomously categorized, on circulating levels of inflammatory markers is not clear. Antibody levels of pathogens have not been examined in relation to inflammation.

Methods: Using data from a subsample of the Multi-Ethnic Study of Atherosclerosis, we examined circulating levels of interleukin-6 (IL-6), C-reactive protein (CRP) and fibrinogen in relation to five common persistent pathogens: cytomegalovirus, herpes simplex virus-1, Hepatitis A virus, Helicobacter pylori and Chlamydia pneumoniae. We tested the hypothesis that the number of seropositive pathogens (based on conventional cut-off points) would not be as sensitive a marker of inflammation as immune response measured by antibody levels to pathogens.

Results: High antibody response to multiple pathogens showed graded and significant associations with IL-6 ( $p<$ $0.001)$, CRP $(p=0.04)$ and fibrinogen $(p=0.001)$, whereas seropositive pathogen burden did not. In multiple linear regression models, high antibody response to multiple pathogens maintained a positive association only with IL-6 (4.4\% per pathogen exhibiting high antibody response, $95 \% \mathrm{Cl}$ 0.0-8.9).
\end{abstract}

Conclusions: High antibody response to pathogens was a more consistent marker of inflammatory outcomes compared to seropositivity alone and high antibody response to multiple pathogens was a stronger marker compared to any single pathogen.

\section{Background}

Persistent pathogens, those acquired early in life and maintained without causing obvious illness, are implicated in cardiovascular disease etiology. Numerous studies have suggested that persistent viruses such as cytomegalovirus (CMV), herpes simplex virus-1 (HSV), Hepatitis A virus (HAV) and bacterial pathogens such as Helicobacter pylori (H. pylori) and Chlamydia pneumoniae (C. pneumoniae) are associated with cardiovascular disease [1-4], although some studies do not support a significant relationship [5-7]. Effects of

\footnotetext{
*Correspondence: aielloa@umich.edu

${ }^{2}$ Department of Epidemiology, University of Michigan School of Public Health, 1415 Washington Heights, Room 3659, Ann Arbor, Ml 48109, USA Full list of author information is available at the end of the article
}

multiple infectious agents may be synergistic, and some authors suggest that pathogen burden (total number of pathogens) has a greater impact on cardiovascular risk than isolated pathogens $[4,8,9]$. It is hypothesized that the association between pathogens and cardiovascular disease is, in part, mediated through chronic activation of inflammatory pathways $[10,11]$.

In parallel to work linking chronic infections to atherosclerosis, a number of studies have shown that various markers of systemic inflammation are linked to cardiovascular risk. Cytokines such as interleukin-6 (IL-6) induce the production and secretion of acute-phase proteins including C-reactive protein (CRP) and fibrinogen $[12,13]$. Chronic activation of these inflammatory pathways is hypothesized to promote atherogenesis and 
thrombosis [14]. Levels of IL-6 [15,16], CRP [17-19] and fibrinogen [20] show consistent associations with incident coronary events and subclinical disease independent of established cardiovascular risk factors. A number of risk factors for chronic inflammation (including smoking [21], physical activity [22], and obesity [23]) have been identified. However, the influence of persistent pathogens on circulating levels of inflammatory markers is unclear and existing studies have been inconsistent [24-26].

We used data from a large population-based sample to examine associations between infectious agents and inflammatory pathways implicated in cardiovascular disease in healthy adults. We examined circulating levels of IL-6, CRP and fibrinogen in relation to the presence of and antibody response to five pathogens: CMV, HSV, HAV, H. pylori and C. pneumoniae. We hypothesized that the conventional definition of pathogen burden (number of seropositive pathogens using conventional cut-off points) would not be as sensitive a marker of inflammation as an alternative definition also taking into account antibody levels of pathogens.

\section{Methods}

\section{Study sample}

The Multi-Ethnic Study of Atherosclerosis (MESA) is a population-based longitudinal study designed to investigate risk factors for atherogenesis. Study participants $(\mathrm{n}=6814)$, aged 45 to 84 years, were recruited from six US communities and were free of clinical cardiovascular disease at the time of the baseline visit from July 2000 to September 2002. The current cross-sectional analysis uses data on C. pneumonia from the total cohort at baseline, and from a sub-sample of 1000 randomly selected cohort members who underwent serum testing for additional pathogens implicated in cardiovascular disease (CMV, HSV, HAV and H. pylori). Complete information including data on all infectious agents, inflammatory markers and covariables was available for 999 individuals. The Institutional Review Board at each participating site reviewed the study and written informed consent was collected from all participants. Detailed methods and aims of the MESA cohort are available [27].

\section{Data}

During the baseline visit, a range of sociodemographic, behavioral and anthropometric variables were collected. Data included education categorized into four groups (less than high school, high school diploma or equivalent, some college or technical school and college diploma); body mass index (BMI, $\mathrm{kg} / \mathrm{m}^{2}$ ) to define overweight or obesity status as $\geq 25 \mathrm{~kg} / \mathrm{m}^{2}$; current alcohol intake; pack-years of cigarette smoking, current use of medications known to alter inflammatory levels (any one or more of the hormone replacement therapies, aspirin, oral anti-inflammatory agents, lipid-lowering drugs and non-steroidal anti-inflammatory drugs, grouped into a single dichotomous variable); and selfrated health measured on a scale of 1 (best) to 5 (worst); 1-3 were considered "good self-rated health".

\section{Lab tests}

Serum IgG antibodies to CMV, HSV, and H. pylori, were measured by indirect enzyme immunoassay using commercially available kits (DiaMedex Corp. Miami, $\mathrm{FL}$ ). The sensitivity and specificity of the tests ranged from $94-100 \%$. Hepatitis A antibody was measured using the IMx HAVAB qualitative microparticle enzyme immunoassay (Abbott Laboratories, Abbott Park, IL). Immunoglobulin $\mathrm{G}$ antibodies to $C$. pneumoniae were detected using a microimmunoflourescent antibody assay with a range of 0-4 Microimmunofluorescence (MIF) units (Focus Technologies, Cypress, CA). Conventional cut-off points were used to define dichotomous seropositivity; equivocal values were classified as positive. Individuals were considered seropositive for CMV infection above $10.0 \mathrm{EU} / \mathrm{mL}$, HSV infection above 16.0 $\mathrm{EU} / \mathrm{mL}, \mathrm{HAV}$ below a standardized calibrated rate, and H. pylori infection above $0.90 \mathrm{EU} / \mathrm{mL}$ [28]. Infection with C. pneumoniae was considered positive at $1 \mathrm{MIF}$ unit or higher. We defined 'high antibody response' to pathogens as IgG values in the top quartile (lowest quartile for HAV). For C. pneumoniae, titer groups 3-4 were considered high antibody response.

Interleukin- $6(\mathrm{pg} / \mathrm{mL})$ was measured by ultrasensitive ELISA (R\&D Systems, Minneapolis, MN). CRP (mg/L) and fibrinogen $(\mathrm{mg} / \mathrm{dL})$ were assessed by nephelometry (BNII nephelometer, Dade Behring, Deerfield, IL). Analytic coefficients of variation were $6.3 \%, 2.6 \%$, and $3.6 \%$ for IL-6, fibrinogen, and CRP, respectively.

\section{Statistical methods}

Descriptive analyses were carried out using chi-squared tests (for trend where applicable). Kruskal-Wallis rank tests were performed for descriptive variables with skewed distributions. The dependent variables were circulating levels of IL-6 in $\mathrm{pg} / \mathrm{mL}, \mathrm{CRP}$ in $\mathrm{mg} / \mathrm{L}$ and fibrinogen in $\mathrm{mg} / \mathrm{dL}$. Interleukin- 6 and CRP presented skewed distributions and were log-normalized prior to analysis. Independent variables took two forms: 1) seropositive pathogen burden, defined as the count sum of seropositive pathogens using conventional cut-off points (0-5 pathogens with groups 0-1 collapsed for some analyses); and 2) high antibody response to multiple pathogens, defined as the count sum of pathogens with antibody response in the highest quartile (high antibody response to 0-5 pathogens, groups 3-5 collapsed for 
some analyses). We first examined associations of interleukin-6 (IL-6), C-reactive protein (CRP) and fibrinogen with dichotomous measures of high antibody response to each pathogen and second, with the number of pathogens for which there was a high response (0-5). We performed the same analysis using conventional cut-offs for seropositivity to each pathogen and the number of seropositive pathogens.

Tetrachoric (for dichotomous variables) correlation coefficients were calculated to investigate correlations between the different dependent variables and one-way ANOVA was used to test for differences in inflammatory levels according to levels of markers. Linear regression was used to estimate adjusted associations of seropositivity and high antibody levels with inflammatory markers. Four levels of covariate adjustment were used in regression models: 1) adjusted for age and sex; 2) adjusted for age, sex and race/ethnicity; 3) adjusted for age, sex, race/ethnicity and education; and 4) adjusted for all of the above plus body mass index, current alcohol intake, cigarette smoking (pack-years), diabetes, current use of medication and self-rated health.

\section{Results}

The mean age of the sample was 59 years (range 44-84), with $46 \%$ white, $21 \%$ black, $23 \%$ Hispanic and $10 \%$
Chinese. Women comprised $57 \%$ of the sample. Eighteen percent had finished high school but had no college education and $29 \%$ and $37 \%$ of participants had some college education or completed college, respectively. Mean (SD) BMI was $28.6 \mathrm{~kg} / \mathrm{m}^{2}$ (5.6) and $72 \%$ were overweight or obese. Almost $90 \%$ rated their health as good.

Nearly $77 \%$ of the sample was seropositive for CMV, $85 \%$ for HSV, $58 \%$ for HAV, $46 \%$ for $H$. pylori, and $71 \%$ for $C$. pneumoniae. Less than $2 \%$ of the sample was negative for all five of the tested pathogens, whereas $51 \%$ were seropositive for either four or five. Tetrachoric correlation coefficients for seropositivity among pathogens ranged between $0.42-0.55$ except for those involving $C$. pneumoniae, which were weaker and on the order of $0.12-0.24$. All were statistically significant at the $\mathrm{p}<0.05$ level. Median (IQR) levels for IL-6, CRP, and fibrinogen were $1.12 \mathrm{pg} / \mathrm{mL}(0.72-1.74), 2.00 \mathrm{mg} / \mathrm{L}$ (0.82-4.59), and $340 \mathrm{mg} / \mathrm{dL}$ (296-391), respectively.

Table 1 shows the distribution of sociodemographic and health characteristics of the 999-participant sample according to number of seropositive pathogens. There was a positive trend of increasing age by number of pathogens. Non-whites and less educated individuals had higher seropositive pathogen burden (both $\mathrm{p}<$ 0.001). Alcohol consumption was associated with lower seropositive pathogen burden, as was self-rated good

Table 1 Mean (SD) or percent sociodemographic and health characteristics according to seropositive pathogen burden in a sub-sample of the Multi-Ethnic Study of Atherosclerosis (2000-2002)

\begin{tabular}{|c|c|c|c|c|c|c|}
\hline & \multicolumn{5}{|c|}{ Number of seropositive pathogens } & \multirow[t]{2}{*}{ P value* } \\
\hline & $0-1$ & 2 & 3 & 4 & 5 & \\
\hline Age, y & $56.8(8.4)$ & $59.1(9.7)$ & $59.5(10.0)$ & $59.9(10.1)$ & $59.9(9.6)$ & 0.02 \\
\hline Female & 54.6 & 54.6 & 58.5 & 59.4 & 56.1 & 0.8 \\
\hline Race/ethnicity & & & & & & $<0.001$ \\
\hline White & 21.6 & 28.8 & 26.6 & 14.8 & 8.3 & \\
\hline Black & 2.9 & 10.1 & 23.4 & 34.0 & 29.7 & \\
\hline Hispanic & 1.7 & 3.9 & 12.9 & 35.3 & 46.1 & \\
\hline Chinese & 1.0 & 1.0 & 16.2 & 35.4 & 46.5 & \\
\hline Education & & & & & & $<0.001$ \\
\hline$<$ High school & 0.0 & 1.2 & 15.1 & 34.9 & 48.8 & \\
\hline Finished high school & 5.7 & 11.3 & 20.3 & 27.7 & 35.0 & \\
\hline Some college & 8.4 & 16.8 & 25.5 & 26.6 & 22.7 & \\
\hline College graduate & 20.7 & 25.3 & 22.6 & 19.6 & 12.0 & \\
\hline $\mathrm{BMI}, \mathrm{kg} / \mathrm{m}^{2}$ & $28.1(5.4)$ & $27.9(5.3)$ & $28.8(6.1)$ & $28.4(5.5)$ & $28.6(5.7)$ & 0.2 \\
\hline Smoking, pack years & $12.2(30.6)$ & $10.0(17.1)$ & $18.4(30.1)$ & $9.8(18.8)$ & $8.0(14.4)$ & 0.03 \\
\hline Alcohol consumer & 84.6 & 73.3 & 61.8 & 48.8 & 44.4 & $<0.001$ \\
\hline Diabetic & 6.4 & 8.6 & 7.4 & 15.6 & 14.6 & 0.006 \\
\hline Self-rated good health & 95.4 & 93.6 & 90.9 & 85.1 & 78.1 & $<0.001$ \\
\hline $\mathrm{N}$ & 110 & 163 & 217 & 256 & 253 & - \\
\hline
\end{tabular}

Pathogens examined:

*P-values by chi-squared test. (sex, race/ethnicity, education, alcohol use, diabetes, self-rated health), chi-square test for trend (age and BMI), and Kruskal-Wallis test (pack-years of smoking).

BMl: body mass index, $\mathrm{kg} / \mathrm{m}^{2}$.

Alcohol consumer: alcoholic drink within the past week. 
health, whereas smoking and diabetes were associated with a higher pathogen burden.

Table 2 shows inflammatory marker levels by seropositivity and level of antibody response to each pathogen. Seropositivity for individual pathogens was associated with higher inflammatory levels for 11 of the 15 tested associations (all except HAV with CRP and fibrinogen; H. pylori with CRP; and C. pneumoniae with fibrinogen), although only one (HSV with fibrinogen) was significant $(p=0.006)$. HAV infection was significantly associated with fibrinogen as well, but inversely. High antibody response to multiple pathogens, on the other hand, was consistently associated with higher inflammatory levels across all markers, although only four (CMV with all three markers and C. pneumonia with IL-6) were significant.

Figures 1 and 2 show unadjusted inflammatory levels by seropositive pathogen burden and high antibody response to multiple pathogens, respectively. Seropositive pathogen burden was associated with higher circulating levels of IL-6 and fibrinogen but the associations were of borderline significance $(\mathrm{p}=0.07$ and 0.05 for

Table 2 Inflammatory marker levels by seropositivity and high antibody response to each pathogen in a sub-sample of the Multi-Ethnic Study of Atherosclerosis (2000-2002)

\begin{tabular}{|c|c|c|c|c|c|}
\hline Pathogen & $\begin{array}{l}\text { Seropositivity* or } \\
\text { antibody response }\end{array}$ & $\mathbf{N}$ & $\mathrm{IL}-6, \mathrm{pg} / \mathrm{mL}$ & $\mathrm{CRP}, \mathrm{mg} / \mathrm{L}$ & $\begin{array}{l}\text { Fibrinogen, } \\
\mathrm{mg} / \mathrm{dL}\end{array}$ \\
\hline \multirow[t]{6}{*}{ Cytomegalovirus } & Negative & 227 & $1.07(1.04)$ & $1.90(1.08)$ & $345(75)$ \\
\hline & Positive & 758 & $1.18(1.02)$ & $2.01(1.05)$ & $349(73)$ \\
\hline & P-value & - & 0.06 & 0.5 & 0.5 \\
\hline & Q1-Q3 & 510 & $1.13(1.03)$ & $1.83(1.06)$ & $344(75)$ \\
\hline & Q4 & 249 & $1.31(1.04)$ & $2.44(1.08)$ & $360(69)$ \\
\hline & P-value & - & 0.004 & 0.002 & 0.002 \\
\hline \multirow[t]{6}{*}{ Herpes simplex virus-1 } & Negative & 150 & $1.05(1.05)$ & $1.67(1.10)$ & $333(65)$ \\
\hline & Positive & 835 & $1.18(1.02)$ & $2.04(1.04)$ & $351(75)$ \\
\hline & P-value & - & 0.05 & 0.06 & 0.006 \\
\hline & Q1-Q3 & 600 & $1.15(1.03)$ & $2.02(1.05)$ & $350(78)$ \\
\hline & Q4 & 248 & $1.24(1.04)$ & 2.09 (1.08) & $353(68)$ \\
\hline & P-value & - & 0.2 & 0.7 & 0.4 \\
\hline \multirow[t]{6}{*}{ Hepatitis A virus } & Negative & 425 & $1.14(1.03)$ & $2.02(1.06)$ & $353(76)$ \\
\hline & Positive & 574 & $1.17(1.03)$ & 1.95 (1.05) & $342(70)$ \\
\hline & P-value & - & 0.6 & 0.7 & 0.02 \\
\hline & Q2-Q4 & 319 & $1.13(1.04)$ & $1.85(1.07)$ & $348(73)$ \\
\hline & Q1 & 255 & $1.21(1.04)$ & $2.10(1.08)$ & $357(79)$ \\
\hline & P-value & - & 0.2 & 0.2 & 0.2 \\
\hline \multirow[t]{6}{*}{ H. pylori } & Negative & 531 & $1.13(1.03)$ & 1.99 (1.06) & $347(76)$ \\
\hline & Positive & 454 & $1.18(1.03)$ & 1.97 (1.06) & $350(72)$ \\
\hline & P-value & - & 0.3 & 0.9 & 0.5 \\
\hline & Q1-Q3 & 215 & $1.17(1.04)$ & $1.96(1.09)$ & 347 (69) \\
\hline & Q4 & 246 & $1.20(1.04)$ & $1.98(1.08)$ & $352(74)$ \\
\hline & P-value & - & 0.7 & 0.9 & 0.5 \\
\hline \multirow[t]{6}{*}{ C. pneumoniae } & Negative & 288 & $1.14(1.04)$ & $1.90(1.08)$ & $349(77)$ \\
\hline & Positive & 697 & $1.16(1.02)$ & 2.02 (1.05) & $347(72)$ \\
\hline & P-value & - & 0.6 & 0.5 & 0.7 \\
\hline & $\mathrm{T} 1-\mathrm{T} 2$ & 534 & $1.12(1.03)$ & 1.99 (1.05) & $346(72)$ \\
\hline & T3-T4 & 175 & $1.32(1.06)$ & $2.11(1.11)$ & $353(72)$ \\
\hline & P-value & - & 0.005 & 0.6 & 0.2 \\
\hline
\end{tabular}

Presented as geometric mean (SE) for IL-6 and CRP; mean (SD) for fibrinogen.

Q1-Q4 represents lowest through highest quartiles for all pathogens except C. pneumoniae.

T1-T4 represents titer groups for $C$. pneumoniae.

P-values by one-way ANOVA.

${ }^{*}$ Cut-offs for seropositive status: cytomegalovirus $\geq 8.0$ Elisa Units (EU)/mL; herpes simplex virus- $1 \geq 16.0$ EU/mL; hepatitis $A$ virus, rate $\leq 200 ; H$. pylori $\geq 0.90$ EU/ $\mathrm{mL}$; C. pneumoniae $\geq 1.0$ Microimmunofluorescence (MIF) units.

${ }^{\dagger} \mathrm{High}$ antibody response defined as top quartile of antibody response to pathogen (lowest quartile for hepatitis A virus) and titer groups 3-4 for $C$. pneumoniae. Low-intensity defined as bottom three quartiles to pathogens and titer groups 0-2 for C. pneumoniae.. 


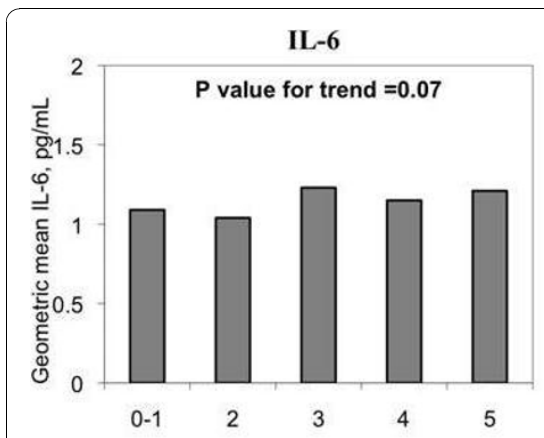

Number of seropositive pathogens

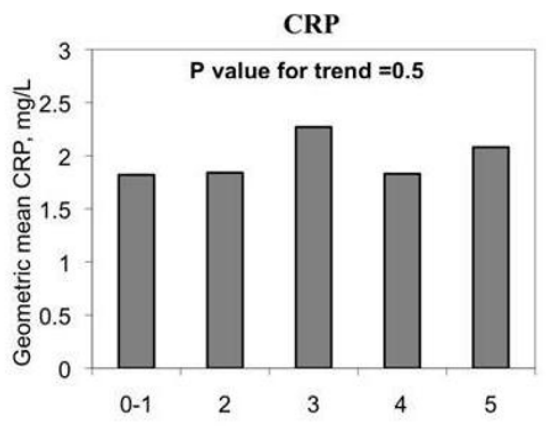

Number of seropositive pathogens

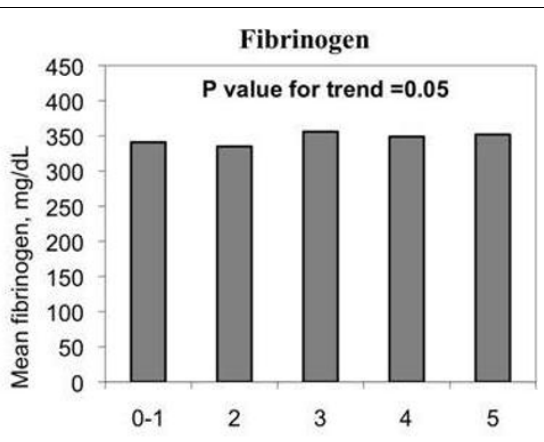

Number of seropositive pathogens

Figure 1 Levels of interleukin-6 (IL-6), C-reactive protein (CRP) and fibrinogen by seropositive pathogen burden in a sub-sample of the Multi-Ethnic Study of Atherosclerosis (2000-2002). P values for trend by linear regression.

trend, respectively). There was no association with CRP. The examination of associations of high antibody levels with inflammatory markers revealed stronger patterns. Levels of IL-6 ( $<<0.001)$, CRP ( $=0.04)$ and fibrinogen $(p=0.001)$ were all significantly and positively associated with high antibody response to multiple pathogens.

Table 3 shows percent differences in inflammatory markers associated with both methods of assessing pathogen burden; seropositive pathogen burden and high antibody response to multiple pathogens, respectively, in four sequentially adjusted models. Positive associations between seropositive pathogen burden and IL- 6 and fibrinogen were modest in model 1 and not statistically significant in adjusted models. In contrast, high antibody response to multiple pathogens was positively and significantly associated with IL-6, CRP and fibrinogen in model 1 , with a 2 to $9 \%$ increase in inflammatory marker level per pathogen exhibiting a high antibody response. Estimates weakened with further adjustment, but associations with IL- 6 remained statistically significant after adjustment for age, sex, race/ ethnicity, and education (approximately 4\% increase per pathogen exhibiting a high antibody response; model 3). Associations were reduced and no longer statistically significant when further adjusted for BMI, behavioral, and health variables (model 4).

Interactions of sex and race with pathogen burden (according to seropositivity or high antibody response) revealed no consistent patterns.

\section{Discussion}

This is among the first studies to evaluate the relationship between pathogen burden based on conventional cut-offs for seropositivity and high antibody response as potential correlates of multiple markers of inflammation. We found that high antibody response was a more consistent marker of inflammatory outcomes than seropositivity alone. Previous work has generally not differentiated between seropositivity and antibody response [29], but our results suggest that this may be an important distinction. Earlier studies showed similar associations with inflammation in many of the pathogens examined here, suggesting that our results are
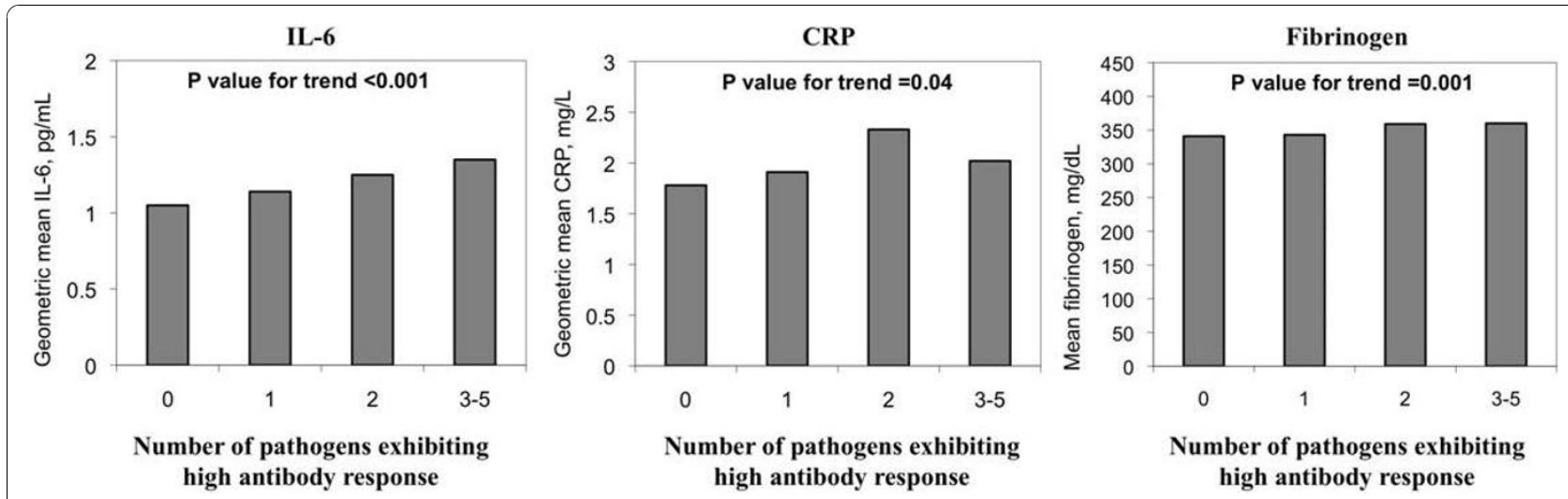

Figure 2 Levels of interleukin-6 (IL-6), C-reactive protein (CRP) and fibrinogen by high antibody response to multiple pathogens in a sub-sample of the Multi-Ethnic Study of Atherosclerosis (2000-2002). P values for trend by linear regression. 
Table 3 Percent difference in inflammatory markers associated with increasing seropositive pathogen burden* and increasing number of pathogens exhibiting high antibody response ${ }^{\dagger}$ in a sub-sample of the Multi-Ethnic Study of Atherosclerosis (2000-2002)

\begin{tabular}{|c|c|c|c|c|c|}
\hline Method & Inflammatory marker & Model 1 & Model 2 & Model 3 & Model 4 \\
\hline \multirow[t]{3}{*}{ Seropositive pathogen burden* } & $\mathrm{IL}-6$ & $2.2(-0.9,5.3)$ & $0.7(-2.9,4.4)$ & $-1.4(-5.0,2.4)$ & $-2.6(-6.0,0.9)$ \\
\hline & CRP & $1.4(-4.1,7.2)$ & $0.5(-5.9,7.3)$ & $-2.0(-8.4,4.9)$ & $-4.2(-10.1,2.0)$ \\
\hline & Fibrinogen & $0.7(-0.3,1.6)$ & $-1.2(-2.3,0.0)$ & $-1.6(-2.7,-0.5)$ & $-1.7(-2.8,-0.6)$ \\
\hline \multirow[t]{3}{*}{ High antibody response to multiple pathogens ${ }^{\dagger}$} & IL-6 & $9.3(4.9,13.8)$ & $5.8(1.5,10.3)$ & $4.4(0.0,8.9)$ & $1.7(-2.4,6.0)$ \\
\hline & CRP & $8.0(0.2,16.4)$ & $4.3(-3.3,12.5)$ & $2.2(-5.3,10.4)$ & $-0.2(-7.3,7.4)$ \\
\hline & Fibrinogen & $2.0(0.7,3.3)$ & $0.7(-0.6,2.0)$ & $0.4(-0.9,1.8)$ & $0.2(-1.1,1.5)$ \\
\hline
\end{tabular}

*Seropositive pathogen burden: seropositivity to 0-5 pathogens analyzed as a continuous variable.

${ }^{\dagger}$ High antibody response to multiple pathogens: high antibody response to 0-5 pathogens analyzed as a continuous variable.

Coefficient $(95 \% \mathrm{Cl})$ shows the percent difference in inflammatory marker level per additional seropositive pathogen or per additional pathogen exhibiting a high antibody response.

Model 1 adjusted for age and sex.

Model 2 adjusted for age, sex and race/ethnicity.

Model 3 adjusted for age, sex, race/ethnicity and education.

Model 4 adjusted for all of the above plus body mass index, alcohol intake, smoking (pack years), diabetes, medications, self-rated health.

compatible with population based estimates [8,26,30-32]. Also in line with previous findings, sociodemographic and health indices were significantly associated with number of seropositive pathogens [28,33-35]. There are less data, however, showing the relationships between sociodemographic characteristics and antibody response in population based studies in the US.

Testing of persistent pathogens often relies on enzyme linked immunosorbent assays (ELISA). These assays provide a qualitative assessment of the amount of antibody in a serum sample. Clinical studies are generally concerned with whether or not individuals tests positive for IgM or IgG to the pathogen of interest and rarely provide data on the qualitative antibody response identified in the ELISA test. Our findings regarding associations of antibody response with inflammation suggests that the qualitative data obtained from an ELISA is an important variable given that this measure predicts inflammation levels. Our findings suggest that antibody levels among the infected, rather than seropositivity is a better marker of inflammatory levels.

Pathogen burden (number of seropositive pathogens) was more strongly associated with inflammation than was any one individual pathogen and seropositivity to pathogens was highly correlated. Pathogen burden has been implicated in cardiovascular disease in several different study populations $[33,36]$. It has been suggested that pathogen burden may not only be a predictor of coronary complications, as previously described, but that it may also be associated directly with the development of atherosclerotic plaques [24]. Zhu and colleagues have suggested that inflammation is one pathway by which these associations are linked [8]. Prasad et al. found that pathogen burden and CRP levels interacted significantly such that carriers of 4-5 pathogens and elevated CRP levels (>0.5 mg/dL) had higher odds of coronary artery disease compared to those with fewer pathogens [4], supporting the notion that pathogen burden along with inflammation has a stronger impact than any one pathogen alone or inflammation alone. A recent study showed that antibody levels to one of the pathogens we examined here, CMV, was associated with an increased rate of cardiovascular mortality among aging individuals [37]. No previous studies have examined the impact of high antibody response to multiple pathogens on inflammatory outcomes.

We found that associations of antibody levels with IL- 6 were more consistent than associations with the other inflammatory markers. In addition, associations with IL-6 persisted after adjustment for age, race and socioeconomic factors but were reduced and no longer statistically significant after adjustment for potential mediators of inflammation such as smoking and obesity. Limited sample size, as well as strong associations between antibody levels and variables such as BMI and smoking may have hampered our ability to detect associations after multiple adjustments. Larger studies are needed to determine whether associations are independent of other risk factors.

There are several possible pathways by which high antibody response to multiple pathogens could impact inflammation more strongly than seropositivity alone. Infection with a particular pathogen may not strongly influence a disease process whereas a strong immune 
response to that pathogen may. Rheumatic heart disease is an example of this phenomenon whereby the immune response to the pathogen (and ensuing inflammation) is the relevant disease process, rather than the infection itself [38]. In the case of infections occurring early in life and persisting over time (likes several of the pathogens we studied); a higher initial infectious dose may lead to a more vigorous antibody response at a young age which is maintained over the life course for persistent infections. Since persistent infections are generally acquired early in life [39], the long term effects of high antibody response may lead to chronically higher levels of inflammation. However, it is not clear why individuals exhibit differentials in antibody response to pathogens. Recent work has indicated that lower socioeconomic position and exposure to chronic stressors may lead to a higher antibody response to CMV, HSV, and $H$. pylori $[28,40]$. Indeed, there are several experimental studies that have demonstrated significant relationships between exposure to psychosocial stressors and a high antibody response to persistent herpes virus (see Herbert and Cohen 1993 for review). Thus, a number of host characteristics may influence antibody response to an infection. Additional studies are needed to better understand the mechanisms by which antibody response may influence systemic inflammation over the life course.

Some methodological considerations of this study warrant mention. Relatively small sample sizes may have affected our ability to detect associations with all markers. The inflammatory outcomes we tested could have been influenced by a number of factors that were not measured or measured imprecisely, even though care was taken to account for several potentially inflammatory conditions and medications that may impact inflammation. Our models also did not account for recent or current acute inflammatory states, such as those associated with the common cold, which may have impacted our findings. Antibody and biomarker levels were only measured once and intra-individual variation cannot be accounted for. However, assay variability would be expected to bias findings towards the null so the observed associations are potentially underestimations. Also, IgG antibody response provides data on past infection- we did not examine data on recent infection or DNA shedding of the viruses and cannot assess whether individuals were experiencing reactivation of the infection. The cross-sectional nature of this analysis precludes implications of causality, and specifically, we cannot rule out the possibility that higher inflammatory status may have led to higher levels of antibodies via activation of the immune response. Four racial/ethnic groups were represented in our data, adding an important strength to our study; however, findings may not be representative of other ethnic or age groups. Finally, it is important to note that viral and bacterial infectious agents may act through different mechanistic pathways to impact inflammation, but assessment of alternative biological pathways, such as infection residing within the cardiovasculature, was beyond the scope of this cross-sectional observational study.

\section{Conclusions}

In summary, high antibody response to multiple pathogens emerged as a better marker of inflammation compared to seropositivity status alone. Our findings suggest that future studies should consider including antibody response data in addition to seropositivity classification of pathogens. Technological advances for refining measurement of antibody response for persistent pathogens is an important endeavor and may reduce measurement error in this potentially important biomarker. Opportunities for further research also include examination of the mechanistic pathways by which antibody response to pathogens contributes to inflammation as well as to cardiovascular disease and its correlates.

\section{Acknowledgements}

AN, AEA and ADR, were supported by a grant from the Center for Integrative Approaches to Health Disparities P60-MD00249-01. In addition, AEA was supported by the University of Michigan-Medical School, Institute of Gerontology RCDC Fellowship and by R21-NR011181-01 from National Institute of Nursing Research. This work was also supported in part by R01 HL076831 from the National Heart Lung and Blood Institute to ADR. The Multi-Ethnic Study of Atherosclerosis is supported by contracts N01-HC-95159 through N01-HC-95165 and N01-HC-95169 from the National Heart, Lung, and Blood Institute. The authors thank the investigators, staff, and participants of the MESA study for their valuable contributions. A full list of participating MESA investigators and institutions can be found at http://www.mesa-nhlbi.org.

\section{Author details}

'Department of Food Science and Nutrition, California Polytechnic State University, San Luis Obispo, CA, USA. ${ }^{2}$ Department of Epidemiology, University of Michigan School of Public Health, 1415 Washington Heights, Room 3659, Ann Arbor, MI 48109, USA. ${ }^{3}$ Department of Pathology, University of Vermont College of Medicine, Burlington, VT, USA. ${ }^{4}$ Department of Laboratory Medicine and Pathology, University of Minnesota, Minneapolis, MN, USA. ${ }^{5}$ Department of Epidemiology, Johns Hopkins Bloomberg School of Public Health, Baltimore, MD, USA.

\section{Authors' contributions}

$A N, A E A$, and ADR drafted the manuscript and AN performed the statistical analysis. NSJ and MYT conducted the biochemical assays. ADR and MS provided important analytical feedback. All authors critically reviewed and commented on previous versions. All authors read and approved the final manuscript.

\section{Competing interests}

The authors declare that they have no competing interests.

Received: 14 July 2010 Accepted: 17 November 2010

Published: 17 November 2010

\section{References}

1. Nieto FJ, Adam E, Sorlie P, Farzadegan H, Melnick JL, Comstock GW, Szklo M: Cohort Study of Cytomegalovirus Infection as a Risk Factor for Carotid Intimal-Medial Thickening, a Measure of Subclinical Atherosclerosis. Circulation 1996, 94(5):922-927. 
2. Sorlie PD, Adam E, Melnick SL, Folsom A, Skelton T, Chambless LE, Barnes R, Melnick JL: Cytomegalovirus/herpesvirus and carotid atherosclerosis: The ARIC study. J Med Virol 1994, 42(1):33-37.

3. Zhu J, Quyyumi AA, Norman JE, Costello R, Csako G, Epstein SE: The Possible Role of Hepatitis A Virus in the Pathogenesis of Atherosclerosis. $J$ Infect Dis 2000, 182(6):1583-1587.

4. Prasad A, Zhu J, Halcox JPJ, Waclawiw MA, Epstein SE, Quyyumi AA: Predisposition to Atherosclerosis by Infections: Role of Endothelial Dysfunction. Circulation 2002, 106(2):184-190.

5. Haider AW, Wilson PWF, Larson MG, Evans JC, Michelson EL, Wolf PA, O'Donnell CJ, Levy D: The association of seropositivity to Helicobacter pylori, Chlamydia pneumoniae, and cytomegalovirus with risk of cardiovascular disease: A prospective study. J Am Coll Cardiol 2002, 40(8):1408-1413.

6. Ridker PM, Hennekens $\mathrm{CH}$, Buring JE, Kundsin R, Shih J: Baseline IgG Antibody Titers to Chlamydia pneumoniae, Helicobacter pylori, Herpes Simplex Virus, and Cytomegalovirus and the Risk for Cardiovascular Disease in Women. Ann Intern Med 1999, 131(8):573-577.

7. Havlik RJ, Blackwelder WC, Kaslow R, Castelli W: Unlikely association between clinically apparent herpesvirus infection and coronary incidence at older ages. The Framingham Heart Study. Arterioscler Thromb Vasc Biol 1989, 9(6):877-880

8. Zhu J, Quyyumi AA, Norman JE, Csako G, Waclawiw MA, Shearer GM, Epstein SE: Effects of total pathogen burden on coronary artery disease risk and C-reactive protein levels. Am J Cardiol 2000, 85(2):140-146.

9. Anderson JL, Carlquist JF, Muhlestein JB, Horne BD, Elmer SP: Evaluation of C-reactive protein, an inflammatory marker, and infectious serology as risk factors for coronary artery disease and myocardial infarction. J Am Coll Cardiol 1998, 32(1):35-41.

10. Epstein SE, Zhou YF, Zhu J: Infection and Atherosclerosis: Emerging Mechanistic Paradigms. Circulation 1999, 100(4):e20-28.

11. Roivainen $M$, Viik-Kajander $M$, Palosuo $T$, Toivanen $P$, Leinonen $M$, Saikku $P$, Tenkanen L, Manninen V, Hovi T, Manttari M: Infections, Inflammation, and the Risk of Coronary Heart Disease. Circulation 2000, 101(3):252-257.

12. Gabay C, Kushner I: Acute-phase proteins and other systemic responses to inflammation. New Engl J Med 1999, 340(6):448-454.

13. Heinrich PC, Castell JV, Andus T: Interleukin- 6 and the acute phase response. Biochem J 1990, 265:621-636.

14. Libby $P$, Ridker PM, Maseri A: Inflammation and Atherosclerosis. Circulation 2002, 105(9):1135-1143

15. Tzoulaki I, Murray GD, Lee AJ, Rumley A, Lowe GDO, Fowkes FGR: CReactive Protein, Interleukin-6, and Soluble Adhesion Molecules as Predictors of Progressive Peripheral Atherosclerosis in the General Population: Edinburgh Artery Study. Circulation 2005, 112(7):976-983.

16. Bermudez EA, Rifai N, Buring J, Manson JE, Ridker PM: Interrelationships Among Circulating Interleukin-6, C-Reactive Protein, and Traditional Cardiovascular Risk Factors in Women. Arterioscler Thromb Vasc Biol 2002, 22(10):1668-1673.

17. Ridker PM, Cushman M, Stampfer MJ, Tracy RP, Hennekens $\mathrm{CH}$ : Inflammation, Aspirin, and the Risk of Cardiovascular Disease in Apparently Healthy Men. N Engl J Med 1997, 336(14):973-979.

18. Hirschfield GM, Pepys MB: C-reactive protein and cardiovascular disease: new insights from an old molecule. QJM 2003, 96(11):793-807.

19. Koenig W, Sund M, Fröhlich M, Fischer H-G, Löwel H, Döring A, Hutchinson WL, Pepys MB: C-Reactive Protein, a Sensitive Marker of Inflammation, Predicts Future Risk of Coronary Heart Disease in Initially Healthy Middle-Aged Men. Results From the MONICA (Monitoring Trends and Determinants in Cardiovascular Disease) Augsburg Cohort Study, 1984 to 1992. Circulation 1999, 99:237-242.

20. Ernst E, Resch KL: Fibrinogen as a Cardiovascular Risk Factor: A MetaAnalysis and Review of the Literature. Ann Intern Med 1993, 118(12):956-963.

21. Frohlich $M$, Sund $M$, Lowel $H$, Imhof $A$, Hoffmeister $A$, Koenig W: Independent association of various smoking characteristics with markers of systemic inflammation in men: Results from a representative sample of the general population (MONICA Augsburg Survey 1994/95). Eur Heart J 2003, 24(14):1365-1372.

22. Colbert LH, Visser M, Simonsick EM, Tracy RP, Newman AB, Kritchevsky SB, Pahor M, Taaffe DR, Brach J, Rubin S, et al: Physical activity, exercise, and inflammatory markers in older adults: findings from the Health, Aging and Body Composition Study. J Am Geriatr Soc 2004, 52(7):1098-1104.
23. Santos AC, Lopes C, Guimaraes JT, Barros H: Central obesity as a major determinant of increased high-sensitivity C-reactive protein in metabolic syndrome. Int J Obes Relat Metab Disord 2005, 29(12):1452.

24. Georges J-L, Rupprecht HJ, Blankenberg S, Poirier O, Bickel C, Hafner G, Nicaud V, Meyer J, Cambien F, Tiret L: Impact of pathogen burden in patients with coronary artery disease in relation to systemic inflammation and variation in genes encoding cytokines. Am J Cardiol 2003, 92(5):515-521.

25. Hermann B, Gabriele B, Margit F, Heiner B, Wolfgang K: Chronic infection with Helicobacter pylori does not provoke major systemic inflammation in healthy adults: results from a large population-based study. Atherosclerosis 1999, 147(2):399-403.

26. Rothenbacher D, Brenner H, Hoffmeister A, Mertens T, Persson K, Koenig W: Relationship between infectious burden, systemic inflammatory response, and risk of stable coronary artery disease: role of confounding and reference group. Atherosclerosis 2003, 170(2):339-345.

27. Bild DE, Bluemke DA, Burke GL, Detrano R, Diez Roux AV, Folsom AR, Greenland P, Jacobs DR Jr, Kronmal R, Liu K, et al: Multi-Ethnic Study of Atherosclerosis: Objectives and Design. Am J Epidemiol 2002, 156(9):871-881.

28. Aiello A, Diez Roux AV, Noone A, Ranjit N, Cushman M, Tsai M, Szklo M: Socioeconomic and Psychosocial Gradients in Cardiovascular Pathogen Burden and Immune Response: The Multi-Ethnic Study of Atherosclerosis. Brain Behav Immun 2009, 23(5):663-671.

29. Lutsey PL, Pankow JS, Bertoni AG, Szklo M, Folsom AR: Serological evidence of infections and Type 2 diabetes: the Multiethnic Study of Atherosclerosis. Diabetic Medicine 2009, 26(2):149-152.

30. Ridker PM, Hennekens CH, Buring JE, Rifai N: C-Reactive Protein and Other Markers of Inflammation in the Prediction of Cardiovascular Disease in Women. N Engl J Med 2000, 342:836-843.

31. Ford ES, Giles WH, Mokdad AH, Myers GL: Distribution and Correlates of C-Reactive Protein Concentrations among Adult US Women. Clin Chem 2004, 50(3):574-581.

32. Tzoulaki I, Murray GD, Price JF, Smith FB, Lee AJ, Rumley A, Lowe GDO, Fowkes FGR: Hemostatic Factors, Inflammatory Markers, and Progressive Peripheral Atherosclerosis: The Edinburgh Artery Study. Am J Epidemiol 2006, 163(4):334-341

33. Zajacova A, Dowd JB, Aiello AE: Socioeconomic and Race/Ethnic Patterns in Persistent Infection Burden Among U.S. Adults. J Gerontol A Bio/ SCi Med Sci 2009, 64A(2):272-279.

34. Albert MA, Glynn RJ, Buring J, Ridker PM: Impact of Traditional and Novel Risk Factors on the Relationship Between Socioeconomic Status and Incident Cardiovascular Events. Circulation 2006, 114(24):2619-2626.

35. Petersen KL, Marsland AL, Flory J, Votruba-Drzal E, Muldoon MF, Manuck SB: Community Socioeconomic Status is Associated With Circulating Interleukin-6 and C-Reactive Protein. Psychosom Med 2008, 70(6):646-652

36. Espinola-Klein C, Rupprecht HJ, Blankenberg S, Bickel C, Kopp H, Rippin G, Victor A, Hafner G, Schlumberger W, Meyer J: Impact of Infectious Burden on Extent and Long-Term Prognosis of Atherosclerosis. Circulation 2002, 105(1):15-21.

37. Strandberg TE, Pitkala KH, Tilvis RS: Cytomegalovirus Antibody Level and Mortality Among Community-Dwelling Older Adults With Stable Cardiovascular Disease. JAMA 2009, 301(4):380-382.

38. Guilherme L, Ramasawmy R, Kalil J: Rheumatic Fever and Rheumatic Heart Disease: Genetics and Pathogenesis. Scand J Immunol 2007, 66(23):199-207.

39. Staras SAS, Flanders WD, Dollard SC, Pass RF, McGowan JE Jr, Cannon MJ: Cytomegalovirus seroprevalence and childhood sources of infection: A population-based study among pre-adolescents in the United States. J Clin Virol 2008, 43(3):266-271.

40. Dowd JB, Aiello AE: Socioeconomic Differentials in Immune Response. Epidemiology 2009, 20(6):902-908.

\section{Pre-publication history}

The pre-publication history for this paper can be accessed here: http://www.biomedcentral.com/1471-2458/10/706/prepub

\section{doi:10.1186/1471-2458-10-706}

Cite this article as: Nazmi et al:: The influence of persistent pathogens on circulating levels of inflammatory markers: a cross-sectional analysis from the Multi-Ethnic Study of Atherosclerosis. BMC Public Health 2010 10:706. 